\title{
Cause of Housing Segregation: Result of Public Policies?
}

\author{
KAZUO MATSUBAYASHI \\ University of Utah \\ USA
}

\begin{abstract}
In many large American cities there is a growing phenomenon of the housing segregation between the rich, the poor and the middle class. This paper points out that such segregation is often caused by the public policies encouraging free market real estate development. The result is a disturbing urban condition in which it is geography of the power is directly reflective of housing locations. Such a condition contradicts the American ideal of democracy. This paper addressed the following factors which cause housing segregation; freeways, property tax deduction, zoning and ordinance, housing as a speculative investment commodity, and race and gender discrimination. The paper claims that the capitalism market system cannot remedy the problem, believes that every one is entitled to decent housing, and suggests that any solution will need to accommodate drastic non-capitalism strategies.
\end{abstract}

The housing distribution pattern in most large American cities reveals the glaring economic and political power disparity of their residents, often along racial divides. Housing, though it is the background of the urban scene, demonstrates more clearly the value system and defines the urban condition than monumental buildings. In the United States the sprawling suburbia prompted by freeways and automobiles isolates the rich, the middle class, and the poor. The suburban detached homes with two-car garages were once the symbol of American democracy and idealized family. However, free market capitalism, real-estate speculation and the belief in freedom of individuals have perpetuated polarization in our society. As the suburban lots become scarce, the American Dream is turning into merely an illusion for most of the younger generation.

This paper first focuses on the housing issue as a manifestation of the political and economic power distribution of society, and then intends to argue, if the ideals of the American democracy are to be based on equality and fairness shared by all citizens, a new urban housing for all types of family must be developed. This paper believes that a democratic ideal must be reflected in its urban scene, particularly in its housing condition. As many concerned individuals point out, the suburban sprawl can no longer by sustained. The growing interest in new urbanism is a welcome sign, though such a notion is not really new. Most European countries are far more advanced in creating good urban housing, and even the now failed communism once cherished communal ideals. In Japan, though its housing units are often small, many corporations provide company housing to employees. Urban housing based on a masstransit network will restructure the urban geography drastically, and make us live in more closely knit physical settings, and will lead to a more conservation-minded society, rather than the consumption-oriented period of the last fifty years. Above all, this implosion toward the city may provide us an opportunity for people of all ethnic and income levels to learn to live together. Only then does America become a truly democratic society.

[Editor's note: The full text of this paper was not available at the time of publication.] 